\title{
Efektivitas Vitamin B-Kompleks terhadap Gambaran Hematologi Sapi Bali Bunting dan Post-Partus
}

\author{
(The Effectivity of Vitamin B-Complex on Hematology Profile \\ of Pregnant and Post Partus Bali Cattle)
}

\author{
Astiti LGS, Hijriah \\ Balai Pengkajian Teknologi Pertanian Nusa Tenggara Barat \\ Jl. Raya Peninjauan Narmada, Lombok Barat, Nusa Tenggara Barat \\ luhde_astiti@yahoo.com
}

\begin{abstract}
The current study intended to investigate the efectivity of vitamin B-complex administration on pregnant and post partus Bali Cattle. The B-complex is an essential vitamin that required for metabolic process for pregnant and post partus cattle. In this study, 10 pregnant Bali Cattle which has average of $5.5 \pm 1.65$ months of gestation and 11 post partus Bali Cattle with average of $1.3 \pm 0.7$ months of calves age have selected for treatment. Before giving the vitamin B-complex treatment, the blood samples was taken from the first group of treated Bali Cattle (T0), while the blood sample from the second group (T2) was taken 30 days after treatment. The $10 \mathrm{ml} / \mathrm{cattle}$ dosage of vitamin B-complex was intra muscularly (IM) injected. The result showed that the red blood cell (RBC), haemoglobin (HGB) and hematocrit values of the pregnant Bali cattle has decreased on T1 to the level of $13.12,19.66$ and $18.76 \%$ respectively $(\mathrm{P}>0.05)$. In contrary, the WBC value increased to $14.5 \%$ on both $\mathrm{T} 0$ and $\mathrm{T} 1$. On post partus samples the values of the RBC, HGB and hematocrit of $\mathrm{T} 1$ group has experienced an increasing to the level of $15.54 \% ; 27.10 \%$ and $23.03 \%$ respectively $(\mathrm{P}>0.05)$ with WBC value decrease to $28.57 \%(\mathrm{P}>0.05)$ on $\mathrm{T} 0$ treatment. It can be concluded that vitamin B-complex can improve physiological status of post partus Bali Cattle, however a good feed management must be included on pregnant Bali cattle.
\end{abstract}

Key Words: Bali Cattle, Hematology, Vitamin B-complex

\begin{abstract}
ABSTRAK
Pengkajian bertujuan untuk mengetahui efektivitas pemberian vitamin B-kompleks pada sapi bunting dan post partus. Vitamin B-kompleks salah satu vitamin yang sangat diperlukan dalam proses metabolisme terutama ternak dalam kondisi bunting dan post partus. Pengkajian ini menggunakan induk sapi Bali bunting sebanyak 10 ekor dengan rata-rata kebuntingan berumur $5,5 \pm 1,65$ bulan dan sapi Bali post partus sebanyak 11 ekor dengan rata-rata umur anak 1,3 $\pm 0,7$ bulan. Sapi-sapi perlakuan pertama (T0) adalah induk sapi Bali diambil darah sebelum disuntik dengan B-kompleks dan perlakuan kedua (T1) induk sapi Bali diambil darah 30 hari setelah disuntik vitamin B-kompleks. Penyuntikan vitamin B-kompleks pada sapi-sapi perlakuan dilakukan secara intra muscular (IM) dengan dosis $10 \mathrm{ml} /$ ekor. Nilai seldarah merah (RBC), hemoglobin (HGB) dan hematokrit sapi Bali bunting mengalami penurunan pada (T1) sebesar 13,12; 19,66 dan 18,76\% ( $\mathrm{P}>0,05)$ sedangkan nilai WBC meningkat $14,5 \%$ pada (T0) dan (T1). Pada kondisi sapi post partus nilai RBC, HGB dan Hematokrit pada perlakuan (T1) mengalami kenaikan sebesar 15,54; 27,10 dan 23,03\% (P>0,05) dengan nilai WBC perlakuan (T0) menurun $28,57 \%(\mathrm{P}>0,05)$. Penyuntikan vitamin B-kompleks dapat memperbaiki status fisiologis pada sapi Bali post partus sedangkan pada sapi Bali bunting harus disertai dengan manajemen pakan yang baik.
\end{abstract}

Kata Kunci: Sapi Bali, Hematologi, Vitamin B-kompleks 


\section{PENDAHULUAN}

Secara umum usaha peternakan merupakan usaha yang sebagian besar dilakukan oleh petani dan tidak terpisahkan dari kehidupan petani demikian halnya di wilayah Nusa Tenggara Barat (NTB). Usaha peternakan di wilayah NTB seperti di pulau Lombok dikelola secara tradisional dengan jumlah kepemilikan ternak berkisar antara 2-3 ekor. Dengan sistem pemeliharaan ini maka produktivitas ternak terutama ternak pembiakan belum optimal misalnya saja ditunjukkan dengan tingginya angka kematian pedet. Disamping karena manajemen pemeliharaan yang dijalankan menggunakan kebiasaan turun temurun juga karena keterbatasan pengetahuan dan keterampilan peternak tentang teknologi-teknologi baru di bidang peternakan.

Optimalisasi dan peningkatan produktivitas usaha peternakan secara tradisional telah banyak dilakukan oleh Pemerintah Daerah maupun Pemerintah Pusat. Di antaranya adalah dengan pemberian subsidi untuk pelayanan standar di pusat-pusat kesehatan hewan. Adapun pelayanan standar yang diberikan adalah kegiatan promotif berupa pemberian suplemen dan vitamin (Menteri Pertanian RI 2007). Vitamin merupakan senyawa organik yang penting dan sangat diperlukan dalam proses metabolisme tubuh ternak terutama dalam kondisi bunting dan post partus. Salah satu jenis vitamin yang dibutuhkan oleh ternak adalah vitamin B-kompleks. Vitamin B-kompleks merupakan grup vitamin yang larut dalam air terdiri dari vitamin B1 (thiamine), B2 (riboflavin), B3 (niacin atau niacin amide), B5 (pantothenic acid), B6 (piridoksin), B7 (biotin), B9 (folic acid), dan B12 (cobalamins) (Hellmann \& Mooney 2010; Fattal-Valevski 2011). Vitamin ini berperan sebagai kofaktor enzim metabolisme sehingga mampu mempertahankan kesehatan tubuh (Hellmann \& Mooney 2010) dan merupakan vitamin esensial pada fungsi otak (Haskell et al. 2010). Pengkajian ini bertujuan untuk mengetahui efektivitas pemberian vitamin Bkompleks pada sapi Bali dalam kondisi bunting dan setelah partus.

\section{MATERI DAN METODE}

Pengkajian dilakukan di dusun Ijobalit Makmur Kelurahan Ijobalit Kabupaten Lombok Timur Nusa Tenggara Barat pada bulan Juni sampai Desember 2016. Pengkajian menggunakan induk sapi Bali sebanyak 21 ekor dengan komposisi sapi Bali bunting yang digunakan sebanyak 10 ekor dengan rata-rata kebuntingan berumur 5,5 $\pm 1,65$ bulan serta sapi Bali induk post partus (setelah beranak) sebanyak 11 ekor dengan rata-rata umur anak $1,3 \pm 0,7$ bulan. Sapi-sapi perlakuan tersebut dikelompokkan dalam dua perlakuan yaitu perlakuan pertama (T0) induk sapi Bali diambil sampel darah sebelum disuntik dengan vitamin B-kompleks dan perlakuan kedua (T1) induk sapi Bali diambil darah 30 hari setelah disuntik vitamin B-kompleks, untuk memberikan waktu terjadinya perubahan pada sel-sel darah akibat penyuntikan vitamin B-Kompleks. Penyuntikan vitamin B-kompleks pada sapi-sapi Bali perlakuan dilakukan secara intra muscular (IM) dengan dosis 10 $\mathrm{ml}$ /ekor. Vitamin B-Kompleks yang digunakan adalah vitamin B-Kompleks yang tersedia di pasaran yang terdiri dari vitamin B1, vitamin B2 dan vitamin B6. Vitamin B-Kompleks dipilih karena sering digunakan oleh praktisi dan peternak karena memiliki harga yang lebih murah. Sampel darah induk sapi Bali perlakuan diambil melalui vena jugularis sebanyak $\pm 5 \mathrm{~m}$ dengan menggunakan venoject kemudian ditampung dalam tabung berisi antikoagulan ethylene diamine tetra acetic acid (EDTA). Selanjutnya tabung diberi label kemudian dimasukkan ke dalam cool box dan dibawa ke Laboratorium untuk dilakukan analisa nilai hematologi dengan metode digital (automatic hematology analizer) menggunakan alat Sysmex KX-21 yang meliputi: sel darah merah (RBC) (juta/ $\mu \mathrm{l})$, sel darah putih (WBC) $(\mathrm{juta} / \mu \mathrm{l})$, hemoglobin (HGB) $(\mathrm{g} / \mathrm{dl})$ dan hematokrit (\%). 
Data yang diperoleh ditabulasi secara deskriptif menggunakan MS Excel 2007. Selanjutnya untuk melihat perbandingan antar perlakuan dilakukan analisis dengan t-test menggunakan SPSS 17.0.

\section{HASIL DAN PEMBAHASAN}

Hasil analisis rata-rata nilai indeks hematologi terhadap darah sapi induk bunting dan sapi induk post partus perlakuan terlihat pada Gambar 1 dan Gambar 2.

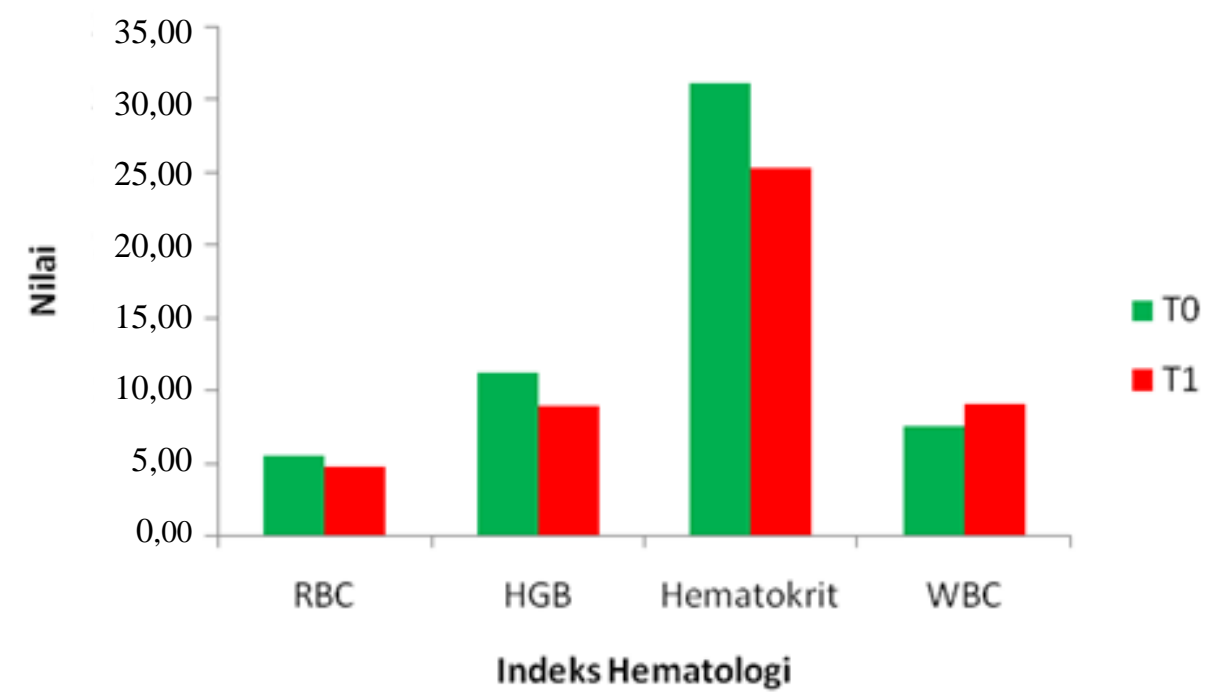

Gambar 1. Grafik efektivitas vitamin B-kompleks pada induk sapi Bali bunting

Berdasarkan hasil analisis hematologi pada Gambar 1. Terlihat bahwa nilai RBC, HGB dan Hematokrit induk bunting sebelum perlakuan (T0) masih dalam nilai normal dan pemberian vitamin $\mathrm{B}$ tidak memberikan pengaruh $(\mathrm{P}>0,05)$. Jika terjadi penurunan nilai RBC dan HGB pada induk bunting perlakuan disebabkan karena pada saat bunting, induk sapi sangat memerlukan nutrisi untuk pertumbuhan fetus. Pemberian vitamin B-kompleks saat ternak bunting sangat dibutuhkan untuk perkembangan fetus, karena vitamin ini merupakan vitamin yang dapat meningkatkan perkembangan fetus terutama vitamin B6, vitamin B9 dan vitamin B-12 (Me'thot et al. 2008; Mitchell et al. 2014) sementara itu pada kajian ini digunakan vitamin B-kompleks yang hanya mengandung vitamin B1, B2 dan B6. Di sisi lain pakan yang diberikan peternak pada induk sapi perlakuan adalah pakan standar yang didominasi rumput alam, sekali waktu diberi rumput gajah atau biomas jagung tanpa pemberian mineral dan suplemen lainnya. Nutrisi yang tidak memadai menyebabkan nilai RBC dan HGB induk tidak mengalami perbaikan. Sehingga pada pengkajian ini pemberian vitamin B-kompleks tidak nyata memberikan perbaikan nilai RBC dan HGB terhadap induk sapi Bunting $(\mathrm{P}>0,05)$. Sedangkan, turunnya nilai Hematokrit pada kajian ini disebabkan karena saat bunting akan terjadi perubahan fisiologis yang mengakibatkan peningkatan volume cairan tanpa diikuti dengan penambahan sel darah merah. Menurut Parra et al. (2005) pada induk bunting akan terjadi peningkatan volume cairan dan penambahan sel darah merah.

Nilai WBC sapi Bunting perlakuan meningkat 14,5\% dari keadaan normal dalam acuan Mitruka et al. (1977) dan hasil penelitian yang dilaporkan oleh Hartaningsih et al. (1983). Pemberian vitamin B-kompleks tidak memberikan pengaruh yang nyata terhadap nilai WBC pada sapi bunting perlakuan $(\mathrm{P}>0,05)$. Hal ini disebabkan karena pada kondisi bunting, terjadi perubahan induk meliputi perubahan fisik, hormonal dan gambaran 
hematologi sebagai akibat adaptasi sistem kekebalan induk terhadap fetus. Keadaan ini menyebabkan penurunan sistem kekebalan tubuh induk sehingga induk bunting lebih peka terhadap infeksi oleh mikroorganisme (Kourtis 2014).

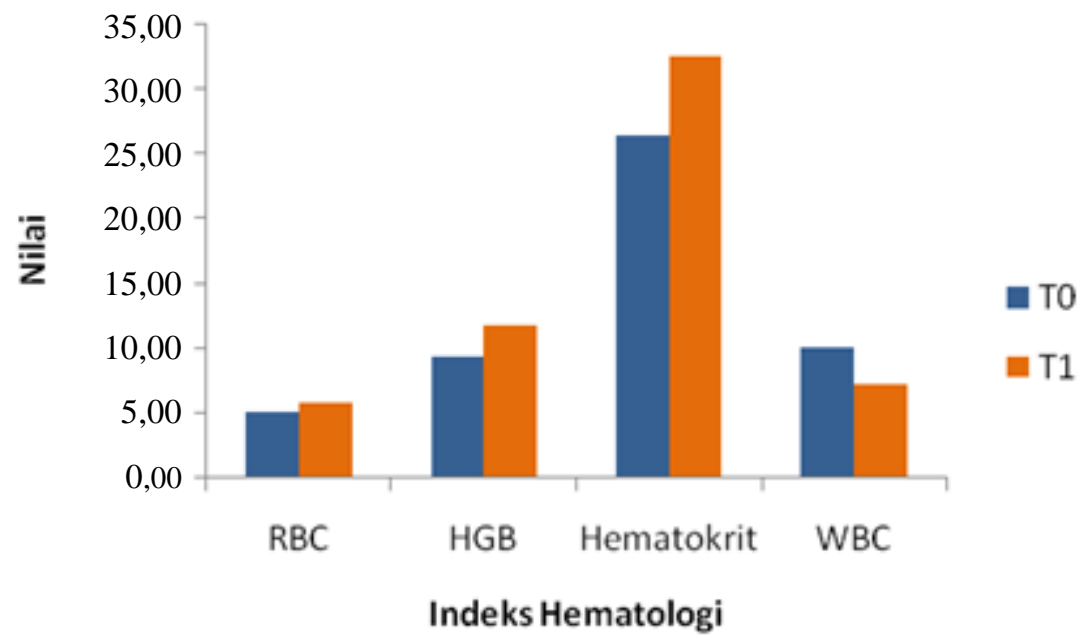

Gambar 2. Grafik efektivitas vitamin B-kompleks pada induk sapi Bali post partus

Pada kondisi induk post partus nilai RBC, HGB dan hematokrit pada perlakuan (T1) tidak mengalami perubahan $(\mathrm{P}>0,05)$ dari kondisi sebelumnya (T0). Nilai WBC sapi post partus perlakuan (T0) menurun sebesar $28,57 \%(\mathrm{P}<0,05)$ akan tetapi masih diatas nilai normal pada acuan Mitruka et al. (1977) dan hasil penelitian yang dilaporkan oleh Hartaningsih et al. (1983). Pada kondisi post partus induk sapi mengalami stres. Kondisi ini merangsang pembentukan $\mathrm{CRH}$ (corticotropin releasing hormone) yang kemudian memberi sinyal ke hipofise anterior menghasilkan ACTH (adrenocorticotropic hormone) untuk mengeluarkan glukokortikoid (Sahin et al. 2003; Boonstra 2005). Glukokortikoid dapat menurunkan sistem imunitas tubuh yang terlihat pada gambaran deferensial leukosit (Zulkifli et al. 2000). Dengan pemberian vitamin B-kompleks dapat mengurangi stress karena vitamin B-kompleks terutama vitamin B1 dapat memperbaiki fungsi sinyal neurotransmitter dan mitokondria sel (Du et al. 2014) serta mampu memproduksi substansi yang dapat mengurangi stress (Fattal-Valevski 2011).

\section{KESIMPULAN}

Vitamin B-kompleks belum dapat memperbaiki status fisiologis pada induk post partus begitu pula pemberian vitamin B-kompleks pada induk bunting tidak memberikan pengaruh yang nyata. Disarankan kepada peternak untuk lebih memperhatikan manajemen pakan misalnya dengan pemberian pakan legume dan memberikan vitamin B-kompleks dengan kombinasi vitamin B1, B2, B6, B9 dan B12 secara berkala.

\section{UCAPAN TERIMA KASIH}

Terima kasih disampaikan kepada Kepala Badan Litbang Pertanian, Kepala BBP2TP, Kepala BPTP Balitbangtan NTB dalam program kajian APBN, seluruh peternak di Dusun Ijo Balit Makmur Kabupaten Lombok Timur, Kepala dan staf Dinas Pertanian dan Peternakan Kabupaten Lombok Timur, lurah dan jajarannya, laboran dan tim pengkajian serta seluruh pihak yang telah membantu kegiatan ini. 


\section{DAFTAR PUSTAKA}

Ashoori M, Saedisomeolia A. 2014. Riboflavin (vitamin B2) and oxidative stress: a review. Brit J Nutr. 111:1985-1991.

Beutler E, Waalen J. 2005. The definition of anemia: what is the lower limit of normal of the blood hemoglobin concentration?. Blood J. 107:1747-1750.

Boonstra R. 2005. Coping with changing northern environment the role of stress axis in bird and mammals. J Integr Comp Biol. 44:95-140.

Buehler BA. 2010. Vitamin B2: Riboflavin. J Evidence-Based Complement Altern Med. 16:88-90.

Du J, Ming Z, Hongkun B, Bai L, Yilong D, Chunjie X, Grace YZ, Ioline H, Matthew R, Benedetto V. 2014. The role of nutrients in protecting mitochondrial function and neurotransmitter signalling: Implications for the treatment of depression, PTSD, and suicidal behaviors, critical reviews in food science and nutrition. Food Sci Nutr. 1-73.

Fattal-Valevski A. 2011. Thiamine (Vitamin B1). J Evidence-Based Complement Altern Med. 16:12-20.

Hartaningsih, Sudana IG, Malole M. 1983. Gambaran darah sapi Bali di Bali. Hemera Zoa. 71:155160.

Haskell CF, Robertson B, Jones E, Forster J, Jones R, Wilde A, Maggini S, Kennedy DO. 2010. Effects of a multi-vitamin/mineral supplement on cognitive function and fatigue during extended multi-tasking. Hum Psychopharmacol Clin Exp. 25:448-461.

Hellmann H, Mooney S. 2010. Vitamin B6: A Molecule for Human Health? Molecules. 15:442459.

Kourtis AP, Read JS, Jamieson DJ. 2014. Pregnancy and Infection. The New England J Med. 370:2211-2218.

Menteri Pertanian RI. 2007. Peraturan Menteri Pertanian No.4/Permentan/OT.140/9/2007. Tentang Pedoman Pelayanan Pusat Kesehatan Hewan.

Me'thot H, Girard CL, Matte JJ, Castonguay FW. 2008. Effects of dietary supplements of folic acid on reproductive performance in ewes. Can J Anim Sci. 88:489-497.

Mitchell ES, Conus N, Kaput J. 2014. B vitamin polymorphisms and behavior: Evidence of associations with neurodevelopment, depression, schizophrenia, bipolar disorder and cognitive decline. Neurosci Biobehav Rev. 47:307-320.

Mitruka BJ, Rawnsley HM, Vadehra BV. 1977. Clinical biochemical and hematological reference value in normal experimental animals. New York (USA): Masson Publishing, Inc.

Parra BE, Manjarrés LM, Gómez AL, Alzate DM, Jaramillo MC. 2005. Evaluation of nutritional education and a supplement to prevent anemia during gestation. Biomédica. 25:211-99.

Sahin K, Sahin N, Onderci M, Gursu MF, Issi M. 2003. Vitamin C and E canalliviate negative effect of heat stress in japanese quail. J Vet Sci. 73:307-312.

Sivakumar T, Tagawa M, Yoshinari T, Ybañez AP, Igarashi I, Ikehara Y, Hata H, Kondo S, Matsumoto K, Inokuma H, Yokoyama N. 2012. PCR detection of babesia ovata from cattle reared in Japan and clinical significance of co-infection with Theileria orientalis. J Clin Microbiol. 50:2111-2113.

Sivaprasad M, Shalini T, Shayari D, Vijayalakshmi V, Bhanuprakash GR. 2016. Vitamins B6, Folic Acid, and B12: Molecular functions and prevalence of deficiency in India. Proc Indian Natn Sci Acad 82 No. 5 December 2016. pp. 1395-1412.

Syatriani S. Aryani A. 2010. Konsumsi makanan dan kejadian anemia pada siswi salah satu SMP di kota Makassar. J Kesehat Masy Nas. 4:251-254. 
Zulkifli I, Norma MTC, Chong CH, Loh TH. 2000. Heterophil to lymphocyte ratio and tonic immobility reactions to preslaughter handle in broiler chickens treated with ascorbic acid. J Poult Sci. 79:401-406.

\section{DISKUSI}

\section{Pertanyaan}

Berapa kali pemberian vitamin B-komplek untuk induk bunting dan induk post-partus untuk mendapatkan performa terbaik?

\section{Jawaban}

Untuk mendapatkan performa terbaik induk bunting idealnya dilakukan pemberian vitamin B-kompleks satu bulan sekali selama kebuntingan dan pada induk post partus pemberian vitamin B-kompleks dilakukan juga setiap bulan sekali hingga pedet disapih. 